\title{
E-Report System to Help Monitor Student Academic Progress Using Forward Chaining for Grade Promotion According to Student Development Level
}

\author{
Ibnu Utomo Wahyu Mulyono*1, Novita Kurnia Ningrum² \\ 1,2Departement Computer Science, Universitas Dian Nuswantoro, Semarang, Indonesia 50131 \\ E-mail : ibnu.utomo.wm@dsn.dinus.ac.id ${ }^{* 1}$,novita.kn@dsn.dinus.ac.id ${ }^{2}$ \\ *Corresponding author \\ Zahrotul Umami ${ }^{3}$, Karis Widyatmoko ${ }^{4}$ \\ ${ }^{3}$ Departement of Comunication Studies, ${ }^{4}$ Departement Computer Science, Universitas Dian \\ Nuswantoro, Semarang, Indonesia 50131 \\ E-mail : zahrotul.umami@dsn.dinus.ac.id ${ }^{3}$, karis.widyatmoko@dsn.dinus.ac.id ${ }^{3}$
}

\begin{abstract}
The COVID-19 pandemic that has occurred in the world and Indonesia is one of the affected countries. To limit the rate of transmission of COVID-19, the Ministry of Education issued regulations relating to online schools. With this online school, both parents and teachers need media to be able to monitor students' academic progress as long as online schools are implemented. Therefore, we need a system that can assist teachers and parents in monitoring students' academic progress. In this study, an e-report was designed by incorporating the components of students' academic aspect and students' character aspect. This system is supported by a decision support system using forward chaining to determine the feasibility of a grade increase according to the level of development of the student. The output of this system is student grade reports, advice given to parents and grade promotion decisions based on academic and character aspect
\end{abstract}

Keywords - Online school, e-report, forward chaining, decision support system

\section{INTRODUCTION}

In 2016 the Regulation of the Minister of Education and Culture of the Republic of Indonesia Number 23 of 2016 has been issued concerning Educational Assessment Standards. According to the regulation of the Minister of Education and Culture that year, assessment is the process of collecting and processing information to measure the achievement of student learning outcomes which are manifested in the form of learning outcomes reports. The report on learning outcomes includes aspects of attitudes and aspects of knowledge [1]. Aspects of knowledge obtained based on academic value through the evaluation of student learning outcomes and aspects of attitudes obtained from the character of students during the learning process. Since the COVID-19 pandemic that occurred in Indonesia at 2020, the Minister of Education through the Ministry of Education and Culture (Kemendikbud) issued Circular Letter Number 15 of 2020 which contains Guidelines for the Implementation of Learning From Home in an Emergency Period for the Spread of Covid-19 [2]. In addition, the Expert Staff of the Minister of Education and Culture for Regulation, Chatarina Muliana Girsang conveyed this Circular Number 15 to strengthen the Circular Letter of the Minister of Education and Culture Number 4 of 2020 concerning the Implementation of Education in the Coronavirus Disease 
(Covid-19) Emergency Period [3]. So far, the learning process and the submission of student learning outcomes are carried out directly or offline. With the circular letter from the Minister of Education, it has an impact on the implementation of the teaching and learning process for students and teachers and the submission of reports on student learning outcomes that were originally offline to online. Thus, we need a media that can be used by teachers and parents to jointly monitor the development of student learning outcomes both from the academic aspect and character.

Monitoring the progress of student learning outcomes, which has been in the form of learning report books, with the implementation of the online teaching and learning process, it will be more relevant if student learning outcomes reports are also submitted online. Thus, teachers can inform the progress of their students up to date and parents can monitor their children's progress without having to come offline to school. There are several studies related to the development of a website-based academic system. The first research by Antono, "Development of Academic Assessment Management Information System (Case Study: KB \& TK Permata Hati). In his research, it was stated that the student learning evaluation which was $50 \%$ increased to $94 \%$ after the website-based academic information system was implemented [4]. Another study by Ahmad Sanmorino in the journal "The Design of Notification System on Android Smartphone for Academic Announcement" explains that there are still many educational institutions, especially universities, that only make announcements via telephone, social media groups or short messages (SMS). The media still has many limitations, because students do not know for sure when the information is shared and the content of the information conveyed is also limited. With the Ndrois-based system, information related to notification of learning activities can be easily known by students. In addition, costs can be minimized, the time required is shorter, and storage space is minimized [5]. Furthermore, the research entitled "Building a Web-Based Academic Information System at the Salafiyah AlBaqiyatussa'diyyah Tembilahan Islamic Boarding School" by Abi Burrahman. In his research explained that the service regarding academic information manually is still not efficient and slow in the process of searching for learning outcomes assessment data. With a website-based information system at the Salafiyah Al-Baqiyatussa;diyah Tembilahan Islamic Boarding School, the value data collection is more structured so that the data search process becomes faster and more efficient [6]. The fourth study by Olkhovyk, Oleksandr. Kurchev and friends explained about the problems of learning Physics that have not been able to use technology to assist in the teaching and learning process. So that in this study a dynamic web was created to help the teaching and learning process become more effective. And research conducted by Agâh Tuğrul Korucu and Hasan akir in the journal "Malaysian Online Journal of Educational Technology" describes testing the influence of dynamic web technology on academic achievement in a collaborative and problem-based learning environment. This study uses quantitative research methods by giving pretest and posttest to correspondents. The results after the dynamic web was applied in collaborative learning, showed that the knowledge of students who used the Problem Based Collaborative Environment Developed web got higher academic scores than students who did not use it [7]. In connection with the explanation of the research above, in this study a web-based e-report system will be designed to provide convenience for teachers and parents together to monitor student progress online. This system will be supported by a decision support system, to determine academic values and attitude values in students. The next value is used as a parameter of eligibility for grade promotion. The output of this system is in the form of reports on student learning outcomes that include academic values and attitude values. In addition, the system will also display suggestions to parents regarding the value of learning outcomes that have been obtained. 


\section{RESEARCH METHOD}

\subsection{Collecting Data}

This study uses quantitative data processing, which includes the process of data collection, data reduction, data presentation and the process of drawing conclusions [8]. At the data collection stage, the data obtained in the form of academic value data which includes daily test scores, mid-semester examination scores and end-semester examination scores. While the non-academic value data includes student craftsmanship, student compliance with rules and student initiative in responding to existing problems.

Table 1. Academic Grade of Student

\begin{tabular}{|l|c|c|c|l|}
\hline \multirow{2}{*}{$\begin{array}{c}\text { Non-Academic } \\
\text { Grades }\end{array}$} & \multicolumn{3}{|c|}{ Information } & \multirow{2}{*}{ Result } \\
\cline { 2 - 4 } Undeveloped & Diligent & Compliance & Initiative & \\
\hline \multirow{3}{*}{ Start to develop } & $\mathrm{V}$ & $\mathrm{v}$ & $\mathrm{V}$ & Uncomplate \\
& $\mathrm{V}$ & $\mathrm{V}$ & - & Start to complate \\
& $\mathrm{V}$ & - & - & \\
\hline & $\mathrm{V}$ & $\mathrm{V}$ & $\mathrm{V}$ & Completed \\
\hline \multirow{3}{*}{ Developed } & $\mathrm{V}$ & $\mathrm{V}$ & - & Completed \\
& $\mathrm{V}$ & $\mathrm{V}$ & $\mathrm{V}$ & Completed \\
\hline & $\mathrm{V}$ & $\mathrm{V}$ & $\mathrm{V}$ & Completed \\
& $\mathrm{V}$ & - & $\mathrm{V}$ & Completed \\
\hline
\end{tabular}

Table 1 shows the development of students' non-academic scores which are expressed in three levels, namely undeveloped, starting to develop and developing as expected. The increase in student grades is not only influenced by academic grades, but also the development of academic grades is also included in the assessment aspect. As stated in a ministerial regulation in 2016, that aspects of learning outcomes include academic aspects and aspects of student attitudes or character [1]. The provisions for grade promotion that combine academic and non-academic elements are shown in Table 2 below.

Tabel 2. Graduation of Student Condition

\begin{tabular}{lc}
\hline \multicolumn{1}{c}{ Rule } & Result \\
\hline If the academic grade $<75$ and has not been completed & Not graduated \\
\hline If the academic grade $<75$ and begins to be completed & Gratuated with conditions \\
\hline If the academic grade $<75$ and has been completed & Gratuated with conditions \\
\hline If the academic grade $>=75$ and has not been completed & Gratuated with conditions \\
\hline If the academic grade $>=75$ and begins to completed & Graduated \\
\hline If the academic grade $>=75$ and has been completed & Graduated \\
\hline
\end{tabular}

Table 2. shows that if academic score is $<75$ and haven't completed, than not graduated. If academic score is $<75$ and start to complate, than graduated with conditions. If the academic value is $<75$ and it has been completed, than graduated with conditions. If academic score is $>=75$ and haven't completed it yet, than gratuated with conditions. If academic score is $>=75$ and start to complate, than graduated. and if the academic value is $>=$ 75 and have completed than graduated.

Academic and non-academic value data will be processed by the system using the forward chaining method. Where the system will provide decisions in accordance with the rule based that has been inputted in it. Forward chaining is one method of inference or to help make decisions based on existing facts [9]. Decision making is based on action conditions and 
applies a data-oriented approach, where the data will function as a determinant of the rules that will be executed and produce a conclusion in the form of a decision. With the processing using forward processing, it makes it easier for teachers to input grades and make decisions about student learning outcomes. Table 3 below shows indicator and condition as appropriate with data from the school.

Table 3. Indicator and Condition Table

\begin{tabular}{|c|c|}
\hline Variabel & Keterangan \\
\hline I-01 & Non Academic grade not developed \\
\hline $1-02$ & Non Academic grade start to developed \\
\hline $1-03$ & Non Academic grade developed \\
\hline $1-04$ & Academic grade $\geq 75$ \\
\hline $1-05$ & Academic grade $<75$ \\
\hline $1-06$ & Overbiden point $\geq 80$ \\
\hline I-07 & Overbidden point $<80$ \\
\hline K-01 & Graduated \\
\hline $\mathrm{K}-02$ & $\begin{array}{l}\text { Graduated, if have a raising grade from semester } 1 \text { to } \\
\text { semester }\end{array}$ \\
\hline K-03 & $\begin{array}{l}\text { Graduated, if have maksimum point of overbiden is less } \\
\text { than equal with } 30 \text { point }\end{array}$ \\
\hline K-04 & Graduated \\
\hline $\mathrm{K}-05$ & $\begin{array}{l}\text { Graduated, if non academic grade have raise up to } \\
\text { developed at semester } 1\end{array}$ \\
\hline K-06 & $\begin{array}{l}\text { Graduated, if non academic grade have raise up to } \\
\text { developed at semester } 1 \text { and academic grade more } \\
\text { than equal with } 75\end{array}$ \\
\hline K-07 & $\begin{array}{l}\text { Graduated, if non academic grade have raise up to } \\
\text { developed at semester } 1 \text { and unobedient point is } \\
\text { maximum } 25 \text { point at semester }\end{array}$ \\
\hline $\mathrm{K}-08$ & Not graduated \\
\hline K-09 & $\begin{array}{l}\text { Graduated and non academic grade is rise to developed at first } \\
\text { semester }\end{array}$ \\
\hline $\mathrm{K}-10$ & Out from scholl \\
\hline $\mathrm{K}-11$ & Out from scholl \\
\hline $\mathrm{K}-12$ & Out from scholl \\
\hline
\end{tabular}

After collecting datas and process it into a appropriate data for the next step, the next step is desiging system with RAD methode. System will design as online website taht could be accessed by the teachers and parents of students, and so they can monitoring and controling students studies and studies activity anywhere they can.

\section{RESULTS AND DISCUSSION}

\subsection{Forward Chaining Implementation}

This step is implementing forward chaining based on indicator and condition that have describes at paragraph above. Table 4 below shows indicator and conditions that was processed and being a rule based for processing data in the system based on forward chaining algorithm. 
Table 4. Rule Based Table

\begin{tabular}{|c|c|c|c|c|c|c|c|}
\hline $\begin{array}{c}\text { Indicator (I)/ } \\
\text { Condition (K) }\end{array}$ & I-01 & I-02 & I-03 & I-04 & I-05 & I-06 & I-07 \\
\hline$K-01$ & $\mathrm{~V}$ & & & $\mathrm{~V}$ & & & $\mathrm{~V}$ \\
\hline$K-02$ & $\mathrm{~V}$ & & & & $\mathrm{~V}$ & & $\mathrm{~V}$ \\
\hline$K-03$ & $\mathrm{~V}$ & & & $\mathrm{~V}$ & & $\mathrm{~V}$ & \\
\hline$K-04$ & $\mathrm{~V}$ & & & & $\mathrm{~V}$ & $\mathrm{~V}$ & \\
\hline$K-05$ & & $\mathrm{~V}$ & & $\mathrm{~V}$ & & & $\mathrm{~V}$ \\
\hline$K-06$ & & $\mathrm{~V}$ & & & $\mathrm{~V}$ & & $\mathrm{~V}$ \\
\hline$K-07$ & & $\mathrm{~V}$ & & $\mathrm{~V}$ & & $\mathrm{~V}$ & \\
\hline$K-08$ & & $\mathrm{~V}$ & & & $\mathrm{~V}$ & $\mathrm{~V}$ & \\
\hline$K-09$ & & & $\mathrm{~V}$ & $\mathrm{~V}$ & & & $\mathrm{~V}$ \\
\hline$K-10$ & & & $\mathrm{~V}$ & & $\mathrm{~V}$ & & $\mathrm{~V}$ \\
\hline$K-11$ & & & $\mathrm{~V}$ & $\mathrm{~V}$ & & $\mathrm{~V}$ & \\
\hline$K-12$ & & & $\mathrm{~V}$ & & $\mathrm{~V}$ & $\mathrm{~V}$ & \\
\hline
\end{tabular}

\subsection{Testing System}

This research using User Acceptance Testing to capture how experiences of user can be used in this system. System developed as suitible as what user need and avalable to used by all of user who will access to the system. Testing system did by the teacher and parent of student [10].

Testing system have been done by 11 of techer. Teachers uses and access fitures of the system and answering questioner after that. Teh result of questioner that answered by teachers showd in Table 5 below

Table 5. Result of Questioner

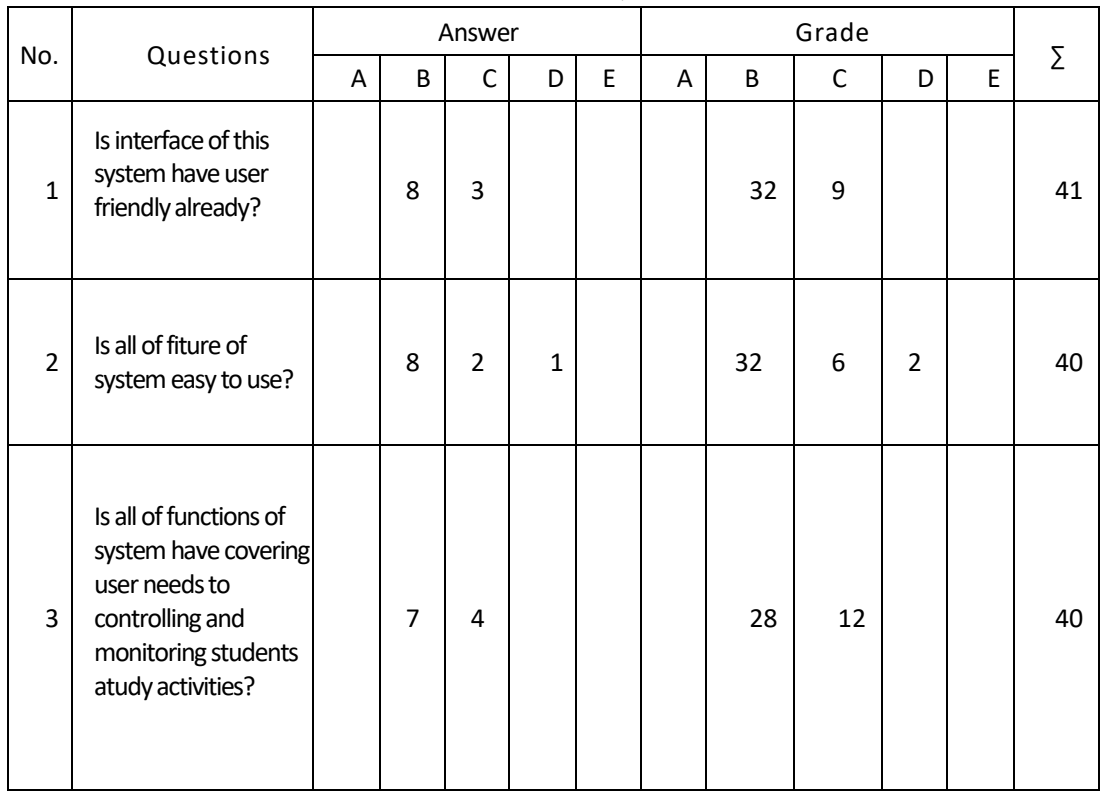




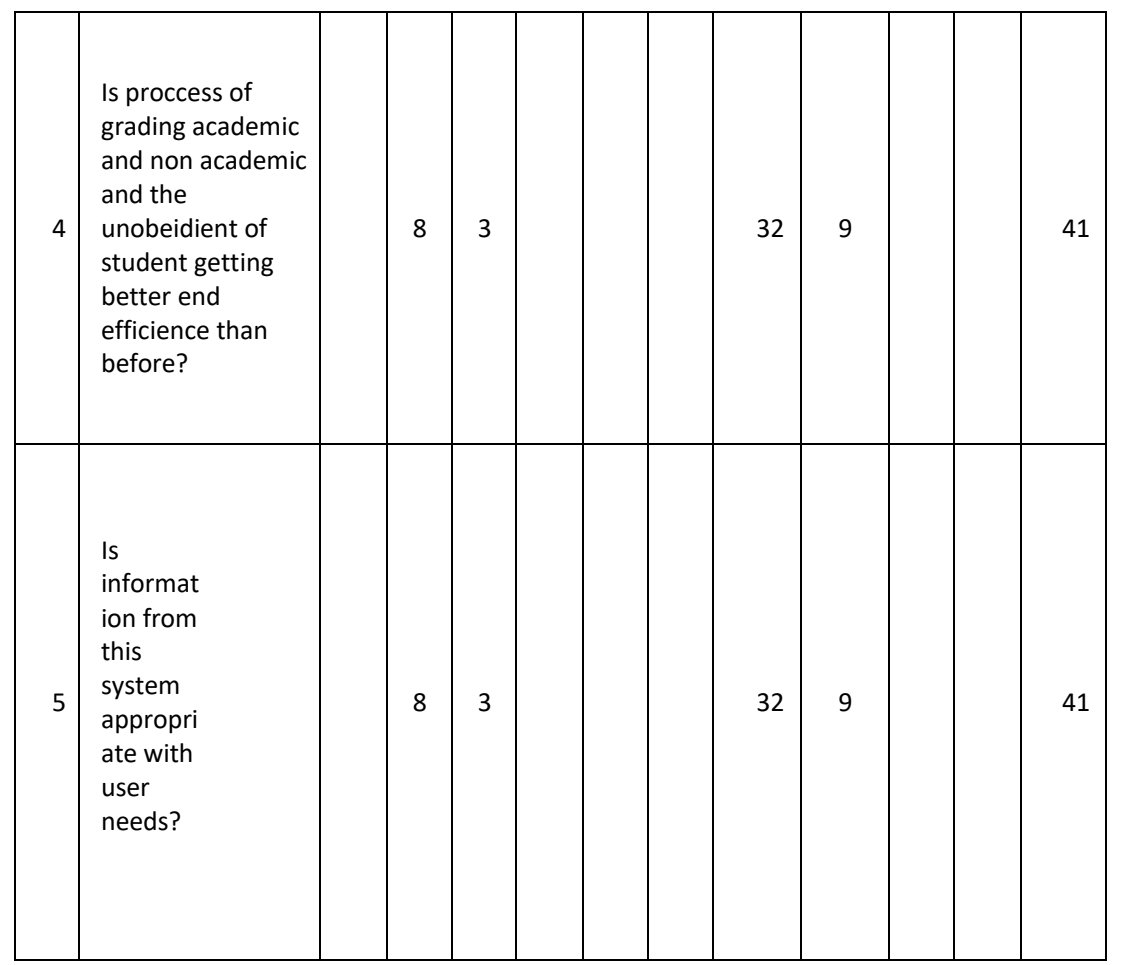

Every answer of the question was given a point. Next step is calculate the point to analize how the feed back of users to the system. The proccess showed by Tabel 6 below.

Tabel 6. Questioner Analysis Table

\begin{tabular}{|r|c|c|}
\hline No & Average Value & Percentage of Value \\
\hline 1 & $41 / 11=3.72$ & $(3.72 / 5) \times 100 \%=74.4 \%$ \\
\hline 2 & $40 / 11=3.63$ & $(3.63 / 5) \times 100 \%=72.6 \%$ \\
\hline 3 & $40 / 11=3.63$ & $(3.63 / 5) \times 100 \%=72.6 \%$ \\
\hline 4 & $41 / 11=3.72$ & $(3.72 / 5) \times 100 \%=74.4 \%$ \\
\hline 5 & $41 / 11=3.72$ & $(3.72 / 5) \times 100 \%=74.4 \%$ \\
\hline
\end{tabular}

Result of questioner anaysis showed taht system can be used by user and more efficince than before

\section{CONCLUSION}

From the test and trial of the reseach can be concluded that forward chainning can used to help grading and make a decicions to decide the graduation of student. And thesystem of website online e report can be used by the user and help user more efficince than before.

\section{REFERENCES}

[1] 2016 and Permendikbud No 23 Tahun, "Peraturan Menteri Pendidikan dan Kebudayaan Republik Indonesia Nomor 23 tentang Standar Penilaian Pendidikan," in Kemendikbud, 2016.

[2] Kemendikbud, "Pedoman Penyelenggaraan Belajar Dari Rumah Dalam Masa Darurat Penyebaran Corona Virus Disease (Covid-19)," in Surat Edaran Nomor 15 Tahun 2020, 
no. 021,2020 , pp. $1-20$.

[3] Kemendikbud, "Pelaksanaan Pendidikan Dalam Masa Darurat Covid-19," Siaran PERS, 2020.

[4] F. I. D. Antono, S. A. Wicaksono, and A. Pinandito, "Development of Academic Assessment Management Information System (Case Study: KB \& TK Permata Iman)," J. Inf. Technol. Comput. Sci., vol. 3, no. 1, pp. 94-103, 2018.

[5] A. Sanmorino and R. M. Fajri, "The design of notification system on android smartphone for academic announcement," Int. J. Interact. Mob. Technol., vol. 12, no. 3, pp. 192200, 2018.

[6] A. Burrahman, "Membangun Sistem Informasi Akademik Berbasis Web Pada Pondok Pesantren Salafiyah Al-Baqiyatussa'Diyyah Tembilahan," Sistemasi, vol. 6, no. 1, p. 33, 2018.

[7] A. T. Korucu and H. Cakir, "The Effect of Dynamic Web Technologies on Student Academic Achievement in Problem-Based Collaborative Learning Environment.," Malaysia Online J. Educ. Techology, vol. 6, no. 1, pp. 92-108, 2017.

[8] D. Kurniadi, M. M. Fauzi, and A. Mulyani, "Aplikasi Simulasi Tes Buta Warna Berbasis Android Menggunakan Metode Ishihara," J. Algoritm., vol. 13, no. 2, pp. 451-456, 2017.

[9] Imhanlahimi R; John-Otumu, "Application of Expert System for Diagnosing Medical Conditions: a Methodological Review," Eur. J. Comput. Sci. Inf. Technol., vol. 7, no. 2, pp. 12-25, 2019.

[10] K. Ganesh, S. Mohapatra, S. P. Anbuudayasankar, and P. Sivakumar, "User Acceptance Test," pp. 123-127, 2014. 